\title{
Penerapan pembelajaran contekstual teaching and learning (CTL) berbantuan hands on activity untuk memahamkan siswa kelas VII-D SMPN 16 Malang pada materi perbandingan
}

\author{
Rachmadhian Maulia Vickamila, Gatot Muhsetyo* \\ Universitas Negeri Malang, Jl. Semarang No. 5 Malang, Jawa Timur, Indonesia \\ *Penulis korespondensi, Surel: gatot.muhsetyo.fmipa@um.ac.id
}

Paper received: 01-12-2021; revised: 15-12-2021; accepted: 31-12-2021

\begin{abstract}
The purpose of this research is revising the way of teaching for making student understand about mathematical ratio through Contextual Teaching and Learning by the use of Hands on Activity. The type of this research is a classroom action research with two cycles, the first cycle consists of four meetings and two meetings of the second cycle. Research's subject is all students class VII-D SMPN 16 Malang, as many as 37 students, consist of 17 men and 20 women. The research activities comprise of learning, class discussions, presentations, and final test.. The data were collected from the result of cyclic final test, the assignment result of students on answering cyclic final test, the result observation about teacher and students activities, interview and field notes. The result indicate that cycle I learning achievement is 80 percent and there are 12 students who made mistakes on the material concept of find a quantity if ratio is known. In the second cycle the percentage of learning achievement is 89,18 percent of the number of students in the classroom and there are 13,88 percent of students still do not understand the material find quantity if ratio is known. Based on these results it can be concluded that the application of a Contextual Teaching and Learning (CTL) approach assisted by hands on activity can make students in grade VII-D SMPN 16 Malang understanding about topics of ratio.
\end{abstract}

Keywords: hands on; understanding; contextual teaching and learning approach

\section{Pendahuluan}

Proses pembelajaran yang sesuai dengan Kurikulum 2013 mampu mendorong siswa untuk aktif, artinya siswa dapat memperluas pengetahuan mereka dan membangun pengetahuan baru (Widyastono, 2015). Dengan mengkonstruksi sendiri pengetahuan, siswa dapat lebih mudah memahami dan mengingat karena siswa terlibat langsung dalam penemuan materi. Selain mampu mengkonstruksi pengetahuan siswa, penilaian pada kurikulum 2013 tidak hanya dilihat dari hasil akhir siswa tetapi lebih menekankan kepada proses siswa dalam memahami dan membangun pengetahuan baru.

Pemahaman adalah cara berfikir logis yang membantu untuk memutuskan apakah dan mengapa jawaban yang telah dipilih benar (Sudaryono, 2012). Siswa paham jika ia dapat mengerti apa yang diajarkan, mengetahui apa yang sedang dikomunikasikan, dan dapat memanfaatkan apa yang telah diperoleh dalam pembelajaran untuk dihubungkan dengan halhal lain. Penilaian pemahaman siswa dapat dilihat dari cara menyelesaikan masalah atau tugas yang berkaitan dengan kebenaran, tanpa ada kesalahan konsep dalam setiap langkah penyelesaian. Namun sifat matematika yang abstrak berupa aturan-aturan untuk menghafal dan sulit dibayangkan membuat siswa kurang mampu memahami suatu materi . Karena sifat matematika yang abstrak diperlukan kreativitas guru dalam pembelajaran matematika. Kreativitas guru dalam pembelajaran matematika dapat dilihat dari sumber daya yang digunakan untuk mengajar matematika yaitu dalam hal mengubah permasalahan kehidupan nyata menjadi contoh yang digunakan untuk mengeksplorasi model matematika (Bolden, 
2010). Menurut Shriki (2009), kreativitas matematika terjadi ketika solusi yang digunakan untuk memecahkan masalah adalah solusi yang tidak standar.

Salah satu pendekatan pembelajaran yang sesuai dengan tumbuh kembangnya ilmu pengetahuan adalah konsep yang dikonstruksi oleh siswa. Sesuai dengan Kurikulum 2013, proses konstruksi melalui kegiatan melakukan dan mencoba serta mengalami sendiri (learning to do) kegiatan yang berkaitan dengan kehidupan sehari-hari, dan disebut dengan pendekatan kontekstual (Rusman 2013). Menurut (Tambelu, 2013; Hudson \& Whisler , 2013; Patmawati, 2013; Sumaji 2010; dan Smith, 2010) pendekatan kontekstual mendorong siswa agar dapat menemukan hubungan materi dengan situasi kehidupan nyata, artinya siswa dituntut untuk dapat menangkap hubungan antara materi yang dipelajari di sekolah dengan kehidupan nyata. Misal permasalahan nyata yang sering dijumpai siswa adalah macammacam diskon yang sering ditawarkan di berbagai pertokoan merupakan salah satu penerapan materi perbandingan dan aritmatika sosial.

Inovasi pembelajaran yang di tawarkan peneliti yaitu pembelajaran matematika dengan pendekatan kontekstual dilengkapi hands on activity. Hands on activity yaitu suatu bentuk pembelajaran dimana siswa memperoleh pengalaman dalam menyelesaikan masalah melalui bentuk benda fisik yang dapat disentuh tangan. Menurut Hilton (2010) siswa lebih senang dan mampu memahami materi melalui hands on activity sehingga siswa dapat lebih aktif dalam proses pembelajaran. Menurut Bogan dkk (2010) hands on atau media manipulatif dapat membantu siswa memahami konsep dengan lebih mudah, dan membuat pengajaran yang lebih efektif, namun guru enggan untuk menggunakannya. Kebanyakan guru masih memandang matematika sebagai subyek sehingga tidak ada tempat kebebasan bagi siswa dan guru untuk berekspresi dan berimajinasi (Bolden 2010).

Berdasarkan hasil tes pada tanggal 22 Agustus 2015 terhadap 10 siswa SMP Negeri 16 Malang kelas VIII diperoleh 80\% siswa kelas VIII tidak memahami dan lupa karena dapat dilihat dari hasil tes bahwa 8 dari 10 siswa telah melakukan kesalahan konsep sejak awal dan memberikan jawaban yang tidak logis tentang materi perbandingan.

\section{Gambar 1 pekerjaan siswa bernama LR}

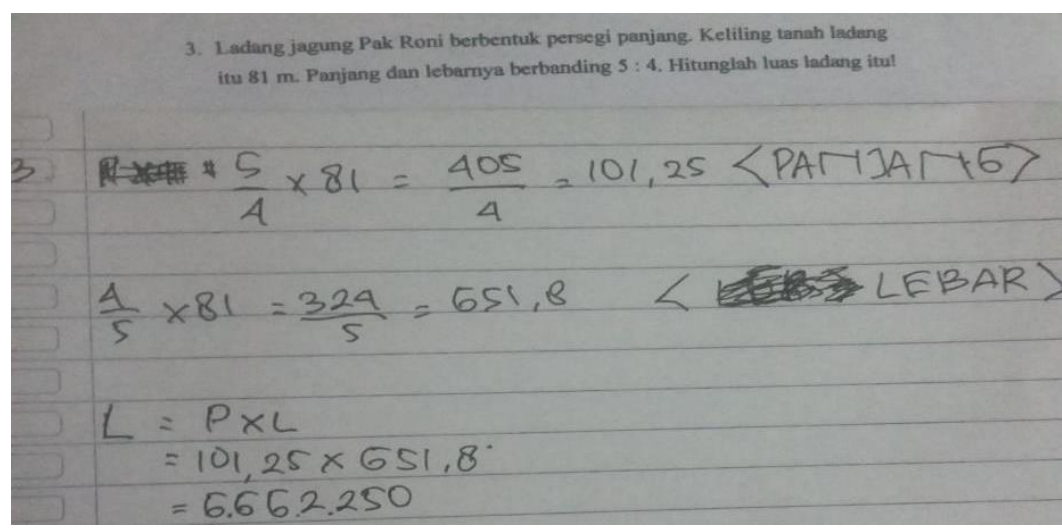

Pemahaman yang kurang dapat disebabkan karena siswa menganggap materi yang dipelajari kurang penting, dan tidak ada aplikasinya dalam kehidupan. Padahal penerapan materi perbandingan sering dijumpai dalam kehidupan misalnya untuk resep makanan, perbandingan harga buah, skala pada peta, dan model barang-barang berskala. Dalam 
pembelajaran, guru dapat menggunakan hands-on berupa foto ukuran yang berbeda atau berskala, pensil dan uang-uangan untuk menghitung perbandingan harga. Hands-on digunakan untuk membantu siswa memahami materi perbandingan, sedangkan pemilihan gambar benda skitar dan uang palsu digunakan untuk menunjukkan kepada siswa bahwa materi materi yang dipelajari sering mereka jumpai bahkan digunakan dan banyak manfaatnya.

Setelah melakukan pengisian kuis kepada 10 siswa SMP Negeri 16 Malang kelas VIII yang telah menempuh materi perbandingan, peneliti melakukan tanya jawab bagaimana pembelajaran yang diterapkan oleh guru pada saat mempelajari materi perbandingan. Seluruh siswa menjawab guru hanya menerangkan di papan tanpa adanya bantuan media, sehingga $80 \%$ siswa tidak tertarik dengan pemblajaran yang diberikan oleh guru. Saat peneliti memberikan pertanyaan lain tentang mengapa siswa tidak tertarik dengan pembelajaran yang telah diberikan oleh guru padahal guru telah memberikan contoh perbandingan pada masalah nyata seperti perbandingan banyak pekerja bangunan dengan waktu yang dibutuhkan pekerja, dan perbandingan luas lahan pertanian. $70 \%$ siswa menjawab karena saya tidak ingin menjadi pekerja bangunan dan tidak memiliki lahan pertanian. Oleh karena itu peneliti memilih metode pembelajaran dengan pendekatan kontekstual berbantuan hands on activity yang dapat menghubungkan materi dngan masalahmasalah yang ada di lingkungan siswa.

Berdasarkan latar belakang yang telah dikemukakan diatas, maka peneliti akan melakukan penelitian yang berjudul "Penerapan Pembelajaran Contekstual Teaching and Learning (CTL) Berbantuan Hands On Activity Untuk Memahamkan Siswa Kelas VII-D SMPN 16 Malang pada Materi Perbandingan"

Secara umum penelitian ini bertujuan untuk mendeskripsikan langkah-langkah penerapan pendekatan Contextual Teaching and Learning (CTL) berbantuan hands on activity yang dapat memahamkan siswa kelas VII-D SMPN 16 Malang pada materi perbandingan.

\subsection{Kajian teori}

\subsubsection{Pembelajaran Contextual Teaching and Learning (CTL)}

Pembelajaran kontekstual (Contextual Teaching and Learning) adalah konsep belajar yang mengaitkan antara materi yang diajarkan dengan situasi dunia nyata untuk menemukan makna yang baru (Taniredja, 2013).

Pembelajaran Contextual Teaching and Learning (CTL) pada penelitian ini yaitu pembelajaran yang menggunakan 7 komponen yang mengacu pada pembelajaran Contextual Teaching and Learning (CTL) Depdiknas (2002) sebagai langkah pembelajarannya yaitu (1) konstruksivisme (contructivism), (2) bertanya (questioning), (3) menemukan (inquiry), (4) masyarakat belajar (learning community), (5) pemodelan (modelling), (6) refleksi (reflection), dan (7) asesmen otentik (authentic assesment).

\subsubsection{Hands-On Activity}

Hands-on activity adalah sebuah media manipulatif matematika yang menggunakan pendekatan visual dan kinestetik . Media manipulatif merupakan "bahan 
ajar yang dirancang untuk disentuh oleh siswa, dan yang dapat mengembangkan kemampuan pemahaman, keterampilan psikomotorik, dan lain-lain".(Haury, 1994). Jadi pembelajaran berbantuan hands on activity adalah pembelajaran dengan melibatkan siswa untuk melakukan kegiatan matematika dengan benda-benda fisik sehingga siswa memiliki pengalaman konkret sebelum belajar konsep matematika yang abstrak. Sehingga dari penelitian yang telah dilakukan Hilton siswa dapat lebih aktif, dan tertarik untuk mempelajari matematika yang bersifat abstrak.

Contoh hands on yang akan digunakan dalam penelitian ini yaitu :

1. Diberikan hands on berupa pensil, bullpen, penggaris, tali

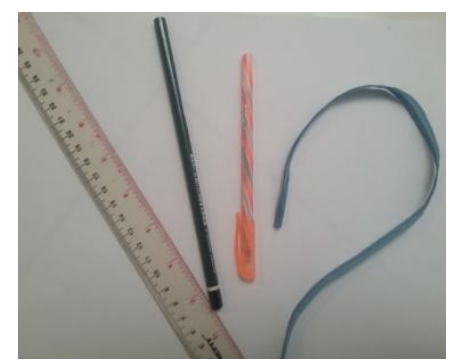

Perhatikan hands-on yaitu bullpen, penggaris, pensil, dan tali yang telah diberikan pada masing-masing kelompok, hitung masing-masing panjang benda tersebut!

\begin{tabular}{|l|l|l|l|l|}
\hline Nama Benda & Bulpen & Penggaris & Pensil & Tali \\
\hline Panjang $(\mathrm{cm})$ & $13 \mathrm{~cm}$ & $30 \mathrm{~cm}$ & $17,5 \mathrm{~cm}$ & $39 \mathrm{~cm}$ \\
\hline
\end{tabular}

a. Tentukan benda yang memiliki panjang 3 kali dari panjang bulpen!

Tali

b. Misalkan $\mathrm{x}$ adalah panjang benda yang memiliki panjang 3 kali dari panjang bulpen,

Perbandingan panjang bulpen dengan benda x adalah 1:3

Jika panjang bulpen $=13 \mathrm{~cm}$, maka:

$$
\begin{aligned}
13: \mathrm{x}=1: 3 \longrightarrow \frac{13}{x} & =\frac{1}{3} \\
13 & \times 3=1 \times x \\
39 & =x
\end{aligned}
$$

Jadi, benda yang memiliki panjang 3 kali dari panjang bulpen adalah tali dengan panjang $39 \mathrm{~cm}$ 
2. Diberikan hands on berupa benang wol kuning dan biru

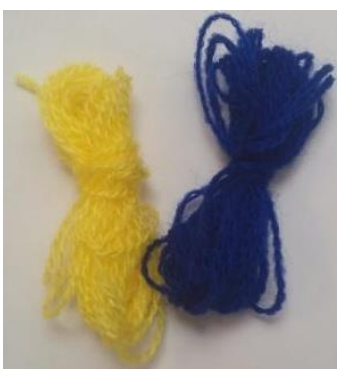

Gunakan hands-on yaitu berupa benang wol yang telah diberikan kepada masing-masing kelompok untuk menyelesaikan masalah pada aktivitas 1 . Ukur dan gunting benang wol tersebut sesuai permasalahan yang telah diberikan!

Sari membeli benang wol dengan panjang $4 \mathrm{~cm}$, sedangkan Rani membeli benang wol dengan panjang $8 \mathrm{~cm}$. Jika Sari ingin mengetahui hubungan panjang benang wol yang telah ia beli dengan panjang benang wol yang dibeli Rani. Tentukan berapa kali lipat panjang benang wol yang dimiliki Sari dengan panjang benang wol yang dimiliki Rani !

\section{Benang wol Sari $1 / 2$ dari benang wol Rani}

a. Perhatikan hands-on yaitu kardus mie instan, gambar balok, foto keluarga yang telah diberikan kepada masing-masing kelompok!

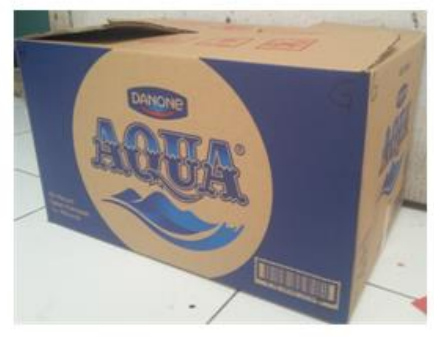

Kardus Aqua

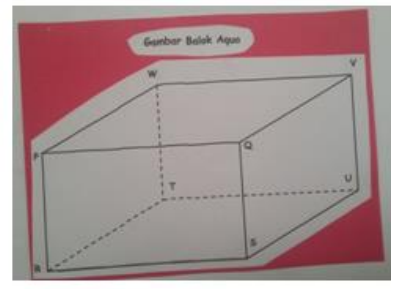

Gambar Berskala Kardus Aqua

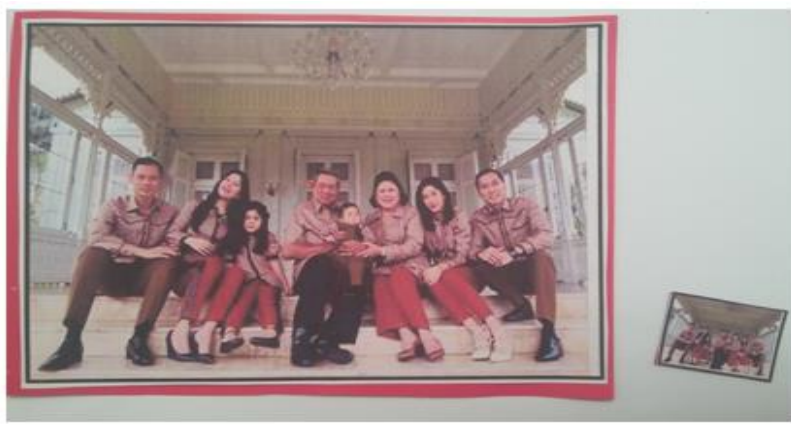

Gambar. Foto Keluarga Ukuran Sebenranya dan Berskalal

Carilah hands-on yang memiliki bentuk yang sama tapi memiliki ukuran yang berbeda. Kemudian ukur setiap sisinya menggunakan penggaris! 
Jika sudah isilah tabel di bawah ini.

\begin{tabular}{|l|l|l|}
\hline Bentuk hands-on & $\begin{array}{l}\text { Ukuran benda } \\
\text { sebenarnya }\end{array}$ & Ukuran benda berskala \\
\hline Kardus Aqua & $\mathrm{AB}=36 \mathrm{~cm}$ & $\mathrm{PQ}=12 \mathrm{~cm}$ \\
& $\mathrm{AC}=21 \mathrm{~cm}$ & $\mathrm{PR}=7 \mathrm{~cm}$ \\
& $\mathrm{DE}=24 \mathrm{~cm}$ & $\mathrm{SU}=8 \mathrm{~cm}$ \\
\hline Foto & $\mathrm{p}_{1}=20 \mathrm{~cm}$ & $\mathrm{p}_{2}=4 \mathrm{~cm}$ \\
& $\mathrm{l}_{1}=15 \mathrm{~cm}$ & $\mathrm{l}_{2}=3 \mathrm{~cm}$ \\
& & \\
\hline
\end{tabular}

Tentukan Skala pada jawaban kalian di atas!

\begin{tabular}{|c|c|}
\hline Bentuk Hands-On & $\begin{array}{l}\text { Skala yang digunakan beserta langkah } \\
\text { untuk mencari skala }\end{array}$ \\
\hline \multirow[t]{4}{*}{ Kardus Aqua } & $\begin{array}{l}\text { Skala }=\quad \frac{P Q}{A B}=\frac{12}{36}=\frac{1}{3} \\
\end{array}$ \\
\hline & $\frac{P R}{A C}=\frac{7}{21}=\frac{1}{3}$ \\
\hline & $\frac{S U}{D \Gamma}=\frac{8}{21}=\frac{1}{2}$ \\
\hline & Skala yang akan digunakan=1:3. \\
\hline \multirow[t]{2}{*}{ Foto } & $\frac{p 2}{p 1}=\frac{4}{20}=\frac{1}{5}$ \\
\hline & $\frac{l 2}{l 1}=\frac{3}{15}=\frac{1}{5}$ \\
\hline
\end{tabular}

b. Gunakan hands-on yaitu berupa pensil dan uang-uangan yang telah diberikan kepada masing-masing kelompok untuk menyelesaikan masalah pada aktivitas 1

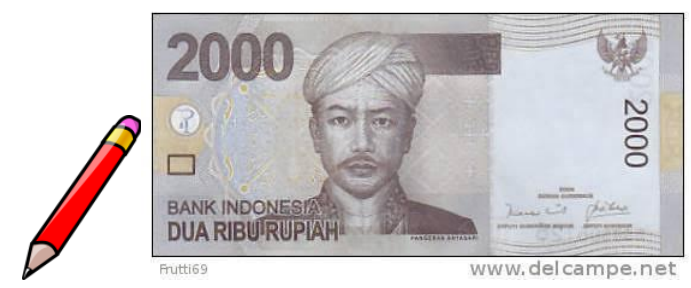

Sony membeli 2 pensil dengan harga Rp.4000,00. Jika keesokan hari Sony ingin membeli 5 pensil berapa uang yang harus dikeeluarkan oleh Sony ? Jika pensil yang dibeli semakin banyak apakah uang yang dikeluarkan oleh Sony semakin banyak/ sedikit?

Semakin banyak pensil yang dibeli semakin banyak uang yang harus dikeluarkan 


\subsubsection{Pemahaman}

Pemahaman adalah cara berfikir logis yang membantu untuk memutuskan apakah dan mengapa jawaban yang telah dipilih benar. Dengan pemahaman siswa dituntut untuk mengerti apa yang diajarkan, mengetahui apa yang sedang dikomunikasikan, dan dapat memanfaatkan isinya dengan menghubungkan dengan permasalahan lainnya (Sudaryono,2012). Pemahaman adalah kemampuan menangkap makna dari sesuatu yang telah dipelajari menjadi suatu pola yang logis dalam menyelsaikan suatu permasalahan. Penilaian yang digunakan untuk mengukur pemahaman adalah penilaian yang harus dilakukan secara konsisten, sistematis, dan terpogram dengan menggunakan tes dan non tes dalam bentuk lisan,pengamatan kinerja,pengukuran sikap, penilaian hasil karya berupa tugas, portofolio serta penilaian diri.

\subsection{Langkah-langkah}

Langkah-langkah pembelajaran contextual teaching and learning berbantuan hands on activity yang akan digunakan pada penelitian ini:

1.2.1. Siswa mengamati masalah contextual teaching and learning yang diberikan guru mengenai materi perbandingan dan skala. Guru mengarahkan siswa untuk berpikir kritis dalam memecahkan masalah.

1.2.2. Siswa melakukan proses pembelajaran secara berkelompok untuk menyelesaikan permasalahan mengenai perbandingan dan skala melalui LKS yang dirancang oleh peneliti dengan bantuan hands on activity yang digunakan untuk membangun konsep perbandingan dan skala dengan bantuan guru.

1.2.3. Siswa bertanya pada guru dan teman sekelompok saat proses pembelajaran berlangsung mengenai permasalahan perbandingan dan skala.

1.2.4. Siswa mendiskusikan permasalahan perbadingan dan skala yang diberikan oleh guru dan menyajikan hasil diskusinya bersama dengan teman sekelompoknya.

1.2.5. Siswa diminta untuk mempresentasikan hasil diskusi kelompoknya di depan kelas. Hasil diskusi disampaikan dengan menjelaskan langkah-langkah penyelesaian dan pendapat mengapa langkah tersebut dipilih.

1.2.6. Siswa menyampaikan gagasannya satu sama lain pada saat presentasi. Kelompok lain memberikan pendapat tentang langkah-langkah penyelsaian yang dipilih oleh kelompok yang maju saat presentasi.

1.2.7. Guru dan siswa menyimpulkan dan merefleksi tentang apa yang didapat selama proses pembelajaran berlangsung meliputi tanya jawab.

1.2.8. Guru menyampaikan tugas pada pertemuan berikutnya.

\section{Metode}

Dilihat dari karakteristik dan tujuan dari penelitian ini, jenis penelitian ini adalah penelitian tindakan kelas (PTK) atau classroom action research (CAR). Arikunto (2014) menyatakan bahwa bila penelitian tindakan yang berkaitan dengan bidang pendidikan dan 
dilaksanakan dalam kawasan suatu kelas maka penelitian ini dinamakan PTK. PTK terdiri dari 4 tahapan atau siklus, yaitu: (1) perencanaan (plan), (2) pelaksanaan tindakan (action), (3) observasi (observation), dan (4) refleksi (reflection). Salah satu tujuan penelitian tindakan kelas ini adalah untuk memperbaiki pelaksanaan praktek dalam proses pembelajaran berdasarkan refleksi mengenai hasil dari tindakan-tindakan yang telah dilakukan oleh peneliti sebelumnya.

\section{Diagram alur penelitian}

Gambar 2 Model Penelitian Tindakan Kelas

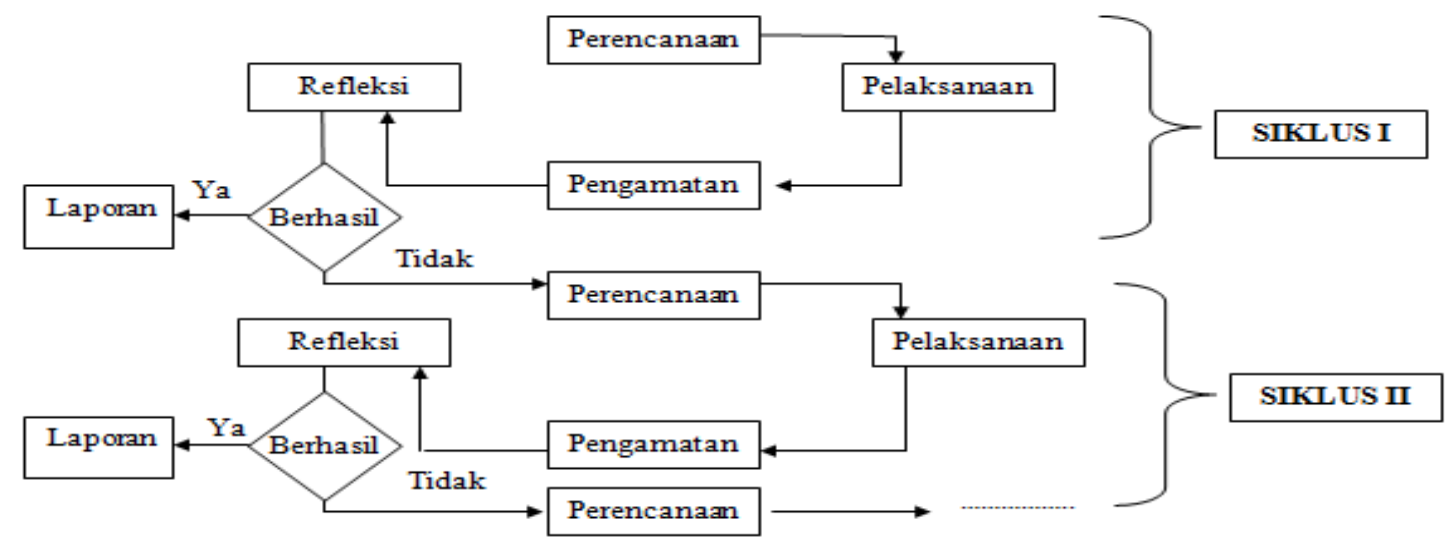

(Diadopsi dari Arikunto. dkk. 2014)

Data penelitian ini diperoleh dari (a) daftar nilai siswa pada materi pecahan yang merupakan materi prasyarat untuk materi perbandingan (b) hasil dialog dengan guru matematika (c) hasil tes tiap siklus setelah penerapan pendekatan Contextual Teaching and Learning (CTL) (d) hasil wawancara dengan siswa yang memiliki nilai kurang dari KKM dan melakukan kesalahan konsep sejak awal penyelesaian, (e) hasil observasi aktivitas guru dan siswa oleh observer, (f) catatan lapangan oleh observer. Sumber penelitian adalah siswa, guru, observer dan peneliti. Dengan kriteria yang digunakan untuk mengukur kberhasilan dalam penelitian tindakan kelas ini adalah sebagai berikut:

1. Presentase banyaknya siswa yang tidak melakukan kesalahan konsep sejak awal peenyelesaian minimal $80 \%$ dari banyak siswa satu kelas, karena suatu kelas dikatakan paham jika paling sedikit $80 \%$ dari banyak siswa dalam kelas tidak melakukan kesalahan konsep sejak awal (Sardiman, 2001).

2. Hasil observasi aktivitas guru dan siswa selama pembelajaran minimal $75 \%$.

3. Presentase banyaknya siswa berkategori tuntas belajar minimal $80 \%$ dari banyaknya siswa satu kelas, karena suatu kelas dikatakan berhasil jika mencapai ketuntasan belajar paling sedikit 80\% dari banyak siswa dalam kelas (Sudaryono, 2012). Kriteria tuntas belajar individu apabila siswa mndapat nilai 75 sesuai KKM.

Jika semua aspek dalam kriteria keberhasilan belum terpenuhi maka perlu dilaksanakan siklus II dengan memperbaiki kekurangan dari hasil refleksi pada siklus I. 


\section{Hasil dan Pembahasan}

\subsection{Hasil}

Penelitian dengan menerapkan pendekatan Contextual Teaching and Learning (CTL) berbantuan hands-on untuk memahamkan siswa di SMP Negeri 16 Malang merupakan penelitian tindakan kelas. Materi yang digunakan dalam penelitian adalah perbandingan, menentukan suatu besaran jika perbandingan diketahui, skala, perbandingan berbalik nilai, dan perbandingan berbalik nilai. Hands-on yang digunakan adalah pensil, bullpen, benang wol, penggaris, tali, kardus aqua, foto, uang-uangan, dan gambar ilustrasi dari kertas asturo. Hands-on digunakan untuk membantu siswa dalam mengkongkritkan masalah yang diberikan kemudian mengarah ke pemikiranyang lebih abstrak. Hal ini sesuai dengan Hilton dkk (2012) penggunaan hands-on dapat menyajikan konsep abstrak matematika dalam bentuk kongkrit dan lebih dapat dipahami dan dimengerti. Penelitian dilaksanakan dalam dua siklus. Setiap siklus terdapat empat tahap penelitian sesuai dengan model penelitian tindakan kelas, yaitu perencanaan, pelaksanaan tindakan, pengamatan/observasi, dan refleksi (Arikunto, dkk, 2014).

Penerapan pendekatan Contextual Teaching and Learning (CTL) dengan berbantuan hands-on yang dimodifikasi dari Rusman (2013) adalah 1) apersepsi pengetahuan prasyarat, 2) pemberian motivasi melalui permasalahan kontekstual, 3) penyampaian tujuan pembelajaran, 3) pembentukan kelompok yang sudah dibentuk sebelumnya, 4) pengerjaan LKS untuk mengonstruk pemahaman mengenai konsep melalui pertanyaan pada LKS dengan berbantuan hands-on dan bimbingan peneliti pada kelompok, 5) presentasi hasil diskusi dengan menjelaskan langkah-langkah penyelesaian, 6) diskusi dengan kelompok lain yang memiliki hasil yang berbeda dan pemberian penguatan pada konsep yang sudah benar dan membenarkan kesalahan konsep yang dilakukan siswa, 7) melakukan refleksi peneliti bersama siswa menyimpulkan pembelajaran dan menyampaikan tugas untuk pertemuan berikutnya.

Pada siklus I beberapa siswa masih terbalik dalam menuliskan perbandingan, tetapi dengan diskusi kelas dan bertanya siswa dapat mengetahui kesalahan dan memahami penyelesaian yang benar. Hal ini sesuai dengan Rusman (2013) dalam rangka pemantapan pemahaman lebih efektif dilakukan lewat diskusi baik kelompok maupun kelas.

Pensil Hijau

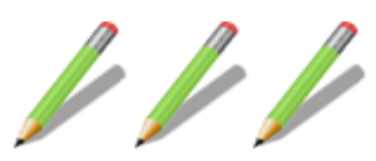

Pensil Biru

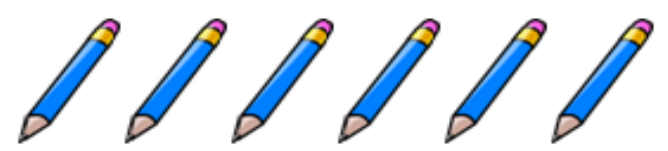

1. Perhatikan hands-on pensil hijau dan pensil biru yang telah diberikan pada masing-masing kelompok.Jika pensil hijau merupakan pensil Aziz dan pensil biru merupakan pensil Sisy maka: 
Gambar 3 Pekerjaan kelompok 2

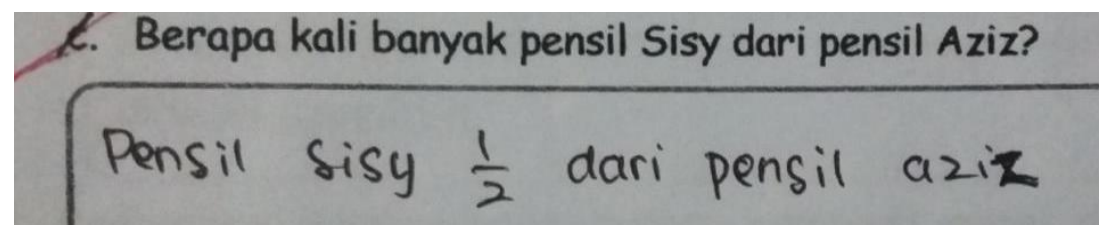

Pada jawaban kelompok 2 siswa menganggap bahwa pensil milik Sisy lebih sedikit dibanding dengan banyaknya pensil milik Aziz. Banyak cara untuk menyelesaikan masalah ini seperti pekerjaan kelompok 3 pada gambar 5.2 dengan membagi banyak pensil Sisy dan banyak pensil Aziz. Jika banyak pensil Sissy 6 dan banyak pensil Aziz 3 maka pensil Sisy 6:3=2 kali banyak pensil Aziz.

\section{Gambar 4 Pekerjaan kelompok 3}

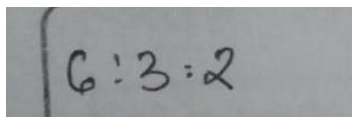

Pada siklus II siswa sudah memanfaatkan buku siswa dengan baik sebagai sumber informasi. Saat proses presentasi semua kelompok lebih kondusif karena jika ada siswa yang ramai guru menunjuk dan menggantikan siswa lain yang sedang presentasi sehingga siswa dapat lebih fokus dan memperhatikan kelompok lain yang sedang presentasi. Meskipun masih ada beberapa siswa yang masih salah dalam menuliskan bilangan dan perhitungan meskipun konsep yang digunakan sudah benar misalnya pekerjaan kelompok 6 pada gambar 5.3. Cara penyelesaian yang diberikan tiap kelompok beragam. Sudaryono (2012) menyatakan bahwa beragamnya pengetahuan konsep, dan ide siswa maka banyak siswa di dalam kelas akan memiliki cara yang berbeda untuk menyelesaikan tugas.

2. Perhatikan hands-on yaitu uang-uangan yang telah diberikan pada masingmasing kelompok untuk menyelesaikan permasalahan berikut:

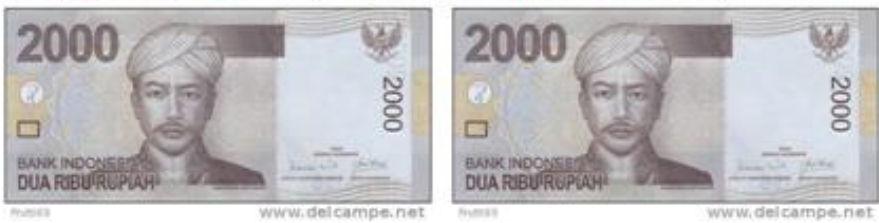

Perbandingan uang saku adik terhadap uang saku kakak adalah 2:5. Jika uang adik adalah Rp. 4000 ,00. Tentukan uang saku kakak!

Gambar 5 Pekerjaan kelompok 6

\section{Uang saku kakak $=\frac{5}{2} \times 4000 \ldots$}

Berdasarkan data yang diperoleh dari hasil observasi guru dan siswa, siklus I taraf keberhasilan aktivitas siswa termasuk dalam kategori "sangat baik" dan taraf keberhasilan aktivitas guru selama pembelajaran termasuk dalam kategori "sangat baik". Pada siklus II 
taraf keberhasilan aktivitas siswa selama pembelajaran termasuk dalam kategori "sangat baik" dan keberhasilan aktivitas guru selama pembelajaran termasuk dalam kategori " sangat baik". Aktivitas yang dilakukan siswa dan guru selama pembelajaran sesuai dengan menggunakan hands-on yang dikemukakan oleh Hilton dkk (2012) proses belajar mengajar termotivasi.

Berdasarkan catatan lapangan siklus I, guru dan siswa kurang memanfaat kan buku siswa dengan baik, beberapa siswa yang tidak aktif dalam kegiatan diskusi, siswa masih ramai saat proses mengkomunikasi. Oleh karena itu pada siklus II guru selalu mengingatkan siswa untuk mencari informasi yang dibutuhkan di buku siswa sehingga pada proses learning community berjalan dengan lancar, beberapa siswa yang kurang aktif saat diskusi sudah mulai berani untuk aktif dan mengajukan pertanyaan jika ada hal yang belum dimengerti karena guru mengingatkan kepada ketua kelompok untuk melaporkan keaktifan setiap anggota. Siklus II pembagian kelompok dan diskusi lebih teratur dan kondusif dibandingkan pada siklus sebelumnya, jika ada siswa yang mulai ramai guru menunjuk untuk menggantikan siswa yang sedang presentasi sehingga semua siswa lebih memperhatikan jalannya presentasi.

Berdasarkan hasil analisis data terhadap hasil tes siswa pada siklus II menunjukkan peningkatan bila dibandingkan dengan siklus I. pada siklus I ketuntasan belajar sebesar $80 \%$ dan terdapat 12 siswa yang melakukan kesalahan konsep sejak awal pada materi menentukan suatu besaran jika perbandingan diketahui, berarti 32,43\% siswa masih belum memahami materi menentukan suatu besaran jika perbandingan diketahui. Pembelajaran siklus I dinyatakan belum berhasil karena siswa yang melakukan kesalahan konsep sejak awal lebih dari 20\%. Beberapa hal yang menyebabkan siklus I belum berhasil diantaranya: 1) guru dan siswa kurang memanfaatkan buku siswa dengan baik padahal buku siswa dapat membantu dalam proses pengonstruksian materi, 2) beberapa siswa yang tidak aktif dalam kegiatan diskusi dan siswa yang sudah memahami materi tidak mau mengajari teman sekelompok yang belum memahami materi, 3) siswa ramai dan tidak memperhatikan saat proses mengkomunikasi, padahal menurut Suherman (2001) pada proses diskusi melalui kebiasaan bertanya dan mengemukakan pendapat dapat membentuk sifat berpikir kritis dan kreatif pada diri siswa.

Pada siklus II persentase ketuntasan belajar siswa mencapai 89,18\% dari banyaknya siswa dalam kelas dan terdapat 5 siswa yang melakukan kesalahan konsep sejak awal pada materi siklus II, berarti $13,88 \%$ siswa masih belum memahami menentukan suatu besaran jika perbandingan diketahui. Sehingga kesalahan konsep yang terjadi kurang dari 20\%.

Peningkatan pemahaman dan ketuntasan siswa pada siklus II dipengaruhi oleh beberapa hal antara lain: 1) siswa sudah memanfaatkan buku siswa dengan baik sebagai sumber informasi, 2) siswa aktif berdiskusi dan mau membantu mengajari teman sekelompok yang belum memahami materi, 3) siswa lebih fokus dan memperhatikan saat proses presentasi dan berani bertanya maupun mengajukan pendapat yang berbeda dengan teman yang presentasi.

\section{Simpulan}

Penerapan pendekatan Contextual Teaching and Learning berbantuan hands on activity yang dapat memahamkan siswa adalah 1) apersepsi pengetahuan prasyarat, 2) pemberian motivasi melalui permasalahan kontekstual, 3) penyampaian tujuan pembelajaran, 3) 
pembentukan kelompok yang sudah dibentuk sebelumnya, 4) pengerjaan LKS untuk mengonstruk pemahaman mengenai konsep melalui pertanyaan pada LKS dengan berbantuan hands-on dan bimbingan peneliti pada kelompok, 5) presentasi hasil diskusi dengan menjelaskan langkah-langkah penyelesaian, 6) diskusi dengan kelompok lain yang memiliki hasil yang berbeda dan pemberian penguatan pada konsep yang sudah benar dan membenarkan kesalahan konsep yang dilakukan siswa, 7) melakukan refleksi peneliti bersama siswa menyimpulkan pembelajaran dan menyampaikan tugas untuk pertemuan berikutnya. Dalam tahap pemberian motivasi melalui pemberian masalah Contextual Teaching and Learning (CTL) dicari masalah yang menarik dan dapat memahamkan siswa mengenai materi yang akan diajarkan. Peneliti menugaskan siswa untuk membaca buku berkaitan dengan materi yang akan diajarkan sebagai sumber informasi yang akan digunakan untuk membantu siswa dalam memahami materi yang akan diajarkan. Siswa diberikan hands on untuk membantu siswa dalam memahami masalah yang diberikan pada LKS. Siswa mengkonstruk pemahaman materi dengan mengerjakan masalah yang disajikan dalam LKS melalui diskusi kelompok dan kelas dengan bantuan hands on dan bimbingan peneliti.

Berdasarkan hasil pengkajian kesalahan konsep, nilai tes dan hasil observasi aktivitas guru dan siswa pada siklus I dan siklus II didapatkan bahwa pendekatan Contextual Teaching and Learning berbantuan hands on activity dapat memahamkan siswa kelas VII-D di SMPN 16 Malang pada materi perbandingan. Hal ini ditunjukkan dengan terdapat 5 siswa atau 13,88\% siswa yang melakukan kesalahan konsep pada materi siklus II dan presentase ketuntasan belajar siswa sudah mencapai $89,18 \%$ dari banyaknya siswa dalam kelas. Pembelajaran siklus II dinyatakan berhasil karena siswa yang melakukan kesalahan konsep kurang dari $20 \%$ dan tingkat ketuntasan siswa sudah mencapai.

\section{Daftar Rujukan}

Arikunto, S, dkk. (2014). Penelitian tindakan kelas. Jakarta: Bumi Askara.

Bogan, dkk. (2010) . Using manipulatives to teach elementary mathematics. Journal of Instructional Pedagogies.

Bolden,D.S, dkk. (2010). Pre-service primary teachers' conceptions of creativity in mathematics. Educ Stud Math Vol 73:143-157.

Depdiknas. (2002). Kurikulum berbasis kompetensi. Jakarta: Pusat Kurikulum Banglitbang Depdiknas

Haury, L.D.RP. (1994). Perspective of hands on science teaching. Columbus: The ERIC Clearinghouse for science, Mthematics, and Environmental Education. http://www.ncrl.org/sdrs/areas/issues/content/cntareas/science/eric/eric-2.htm. [19 Maret 2015]

Hilton, G, dkk. (2013). Propotional reasoning and the visual impaired. National Council of Teachers of Mathematics Vol 18:286-291.

Hudson \& Whisler. (2010). Contextual teaching and learning for practitioners. Systemics, cybernetics and informatics. Volume 6 - Number 4.

Moleong, L. J. (2013). Metode penelitian kualitatif, Bandung: Remaja Rosdakarya.

Nasional, K. P. (2010). Universitas Negeri Malang. Pedoman penulisan karya ilmiah. Edisi ke lima.

Patmawati, D, dkk. (2013). Pembelajaran segitiga dengan pendekatan kontekstual berbasis karakter di kelas VII SMP Negeri 3 Banda Aceh Tahun Pelajaran 2012/2013. Jurnal Pendidikan Matematika PARADIKMA, Vol 6 Nomor 2, hal 120-129.

Rusman. (2013). Model-model pembelajaran. Jakarta : Rajawali

Sardiman. (2001). Interaksi \& motivasi belajar mengajar. Jakarta: RajaGrafindo Persada 
Shriki, A. (2010). Working like real mathematicians: Developing prospective teachers' awareness of mathematical creativity through generating new concepts. Educational Studies in Mathematics, 73(2), 159-179.

Smith, B. P. (2010). Instructional strategies in family and consumer sciences: implementing the contextual teaching and learning pedagogical model. Journal of Family \& Consumer Sciences Education, 28(1).

Sudaryono. (2012). Dasar-dasar evaluasi pembelajaran. Yogyakarta: Graha Ilmu

Suherman, E., dkk, (2001). Strategi pembelajaran matematika kontemporer. Bandung: JICA. Universitas Pendidikan Indonesia.

Tambelu, J.V.A. (2013). Development of mathematical learning based contextual model in south minahasa regency. Journal of Education and Practice. Vol.4, No.15, 2013

Taniredja, T, dkk. (2013). Model-model pembelajaran inovatif dan efektif. Bandung: Alfabeta

Widyastono, H. (2015). Pengembangan kurikulum di era otonomi daerah. Jakarta: Sinar Grafika Offset 